\section{BORGTOCHT EN BELASTINGRECHT}

Ilet ligt niet op onzen weg en behoort niet tot onze competentic on ook den $18 \mathrm{en}$ 'Titcl van lBoek IlI van het I3urgerlijk Wetboek, de artikelen 1857 tot en met 1887, over borgtocht handelende, in de volgende besehouwingen te verwerken. Niettemin mag eenige kemuis ook in de\%e nict ontloreken. He is loijzonder in tijden als deze volop gelegenheid zich als borg te verbinden. Men zij hier'mede cchter voorzichtig. Dit niet enkel ondat de verbintenissen der borgen krachtens alt. 1863 B.W. overgaan op humne erfgenamen. Der Wahn ist kul'z, die Reu ist. ling.

Begröppelijkerwijs heeft zich ook in de tot onderwerj) gekozen materic de rechtsprak in belastingzaken niet onbetuigd gelaten. Zien wo daartoe in de cerste plaats in arrest II. R. 17 $\Lambda$ pril 1929, B. no. $4+92$ een directeur en aundeclhouder van naamlooze vennootschappen optreden, die ten behoeve van die vennootschappen borgtochten aingaat en als ongelukkig gevolg dailvan aan de schuldeischers de sehulden der n.v. heeft aam te zuiveren, wat op een verlies uitkomt. Hetgeen als borer voor: de bewuste n.v. hetald werd, is niet alangemerkt als to zijn geschied in de uitoefening van eenig beroep (of bedrijif), wijl he in de n.v. bekleede functiën niet de noodzaak medebrachten om er voor borg te blijven. Het werd derhalve niet in mindering van het inkomen geleden. Uit dezen hoofde werd deze leidende persomlijkheid bijj de n.v. - wien het caveant consules was ontgaan - tevens cen lijdende partij. Hị werd gerekend en schade enkel in het vermogen te heblsen geleden, die buiten rijn helastbaar inkomen omging. Tussehen het bekleeden van de functic en de geleden schade werd niet geacht ecn nauw verband te bestaan (Damsté, inkomstenbel. 4e druk blz. 135).

'T'rouwens was het niet vooi' de eerste maal, lat een geschil als dit hetzelfde resultaat had bij den administratieven rechter. Te noemen valt Raad van Beroep Groningen 14 September 1921, 13. no. 3083 en ook de Minister van Financiön gaf geljjk richtsnoer (res. 7 Juni 1923, no. 38, 13. no. 3471). De Minister toch gaf te kemnen, dat de borgstelling niet in verband stond met de aan de betrekking verbonden werkzaamheden en $\mathrm{ver}$ plichtingen on niet als cen handeling in den zin van art. $\overline{7}$ der wet op de inkomstenbelasting kon worden aangemerkt.

Werd, zooals zooeven gezien, een verlies uit borgtocht niet als inkomenverlies geleden, ecn los van eenig bedrijf of beroep genoten bate ter zake van bolgstelling ten behoeve van eene naamlooze vennootschap - necrkonende enkel op het plaats hebben van een beschikking over vermogen of het aanvalarden van velmogensrisico - werd niet aangemerkt te vallen onder art. 7 en derhalve evenmin onder art. 18 der wet op de inkomstenbelasting (H. R. 24 April 1929, B. no. 4501). Evenmin gelulkte het blijkens arrest H. R. 19 Juni 1929, B. no. 4527 een verlics uit borgtocht onder art. 18 te brengen met de bewering, dat de garant op de handelingen van den hoofdschuldenaar cen scherpe controle had uitgeocfend. I)it werd niet beschouwd als door den geldsehieter verrichte op zich zolf stande werkzaamheden.

De risico-premie, die iemand ontvangt ter zake, dat hij, in verband met een bedriffstransactie, gedurende een aantal jaren bor'g blijft, bchoort ongetwijfeld tot diens bedrijfswinst, als geldende een in bedrijf gesloten transactie. Blijkens arrest II. R. 12 Dee. 1934, B. no. 5743 wordt ter berekening van de daaruit behalde bate iedere methode toelatatbar geacht, die niet strijdig is met goed koopmansgebruik. Men kan de premie aanstonds ni ontvangst als bate verantwoorden. Men kan eerst het afloopen van den borgtocht afwachten om te zicn welk resultat de transactic heeft opgeleverd. In men kan voor ieder jaar dat de borgtocht duurt een evenredirg deel van de ontvangen risicoprenie als bate aannemen.
Nog zij hicr gememoreend het overbekend geworden, de toepassing van art. 8 der wet op de vermogensbelasting betreffendo arrest II. R. 19 I)ecmber 1934, B. no. 5749. De kans, dat uit hoofde van borgtochtverplichtingen een vermogensmadeel zou worden geleden, mocht - ook al was de borg op 1 Mei van het belastingjaar nog nict tot betaling aangesproken - ingevolge genoend wetsartikel voor de vermogensbelasting als schuld in mindering van de warde der bezitingen gebracht worden. Inest men dit arrest nauwkenrig, dan ziet men de juridisch belangwekkende kwestie der voorwaardeljjke seluuld hier. om den hoek kijken. Doch latat mij als niet-jurist in deze den anderen hoek uitkijken.

'Tot slot in verband met dit onderwerp nog iets over de wet op de Invordering van 's Rijks directe belastingen van 22 Mci 1845, Staatshlad no. 22 De ontvanger, die op den voet valn art. 17, tweede lid, dier wet nitstel van betaling van belasting vellecrt, kan dial'aan bijv. de voorwadrde verbinden van het stel lon van een borg. Nu is echter uit hoofde van zijn borgtocht die borg nog nict de ten kohier gebrachte belastingsehuldige wal'vam art. 5, cerste lid, dier wet gewaagt. Nict de schuldenaar, warrop eventueel de art. 13 en 14 dier wet toegepast kunnen worden. Indien de belastingschuldige zelf in yebrecke bijift, heeft de ontvanger tegen dien borg de gewone actie in to stellen, buiten de Invorderingswet om.

Lat mij hicrmede dit compilatic-artikel hesluiten. Ik vertrouw, lat het niet zal nalaten in voorkmente gevallen eer juist oordecl te helpen vestigen.

\section{B. VAN DEN BLER}

\section{UIT HET BUITENLAND \\ Red.: CH. HAGEMAN, Drs. A. TH. DE LANGE, A. M.VAN RIETSCHOTEN en Drs. E. P. M.VAN WAES (Bijdragen en mededeelingen zende men aan den Secretaris der Redactie)}

\section{Het honorarium van den accountant}

In Engelsche vakbladen is in den liatsten tijd het vralagstuk, op welke basis het honorariun van den aceountant moet worden berekend ter sprake gekomen naıl aanleiding van een proces, dat een accountant tegen zijn opdrachtgever heeft gevoerd. De accountant, die bij een belastingzaak een perecntage van het door zijn inmenging verkregen bespaarde bedrag had bedongen, reclameerde con gedeelte van het bedrag, dat bespaard zou zijn geworden, indien de opdrachtgever den raad van den accountant zou hebben opgevolgd.

Als prineipicele kwestic werd gesteld of de accountant zijn honorarium mag bepalen op basis van de behalde resultaten. In The Accountant van 22 Juni 1935 worlt hetcreen Pixley indertijd heeft gezegd aangehaald nI. "That is a matter which has come up on several occasions at meetings of the Council, and, from remarks I recollect having heard, members consider it is unprofessional to aceept any matter of business on payment by results. We do not think it is a proper thing to do."

Eenzelfde meening is door Sir John Simon tot uitdrukking gebracht door to zeggen: "The work that we do must be rendered to our clients, without stint, in proportion to our elients 'needs, rather than in proportion to the reward which we receive."

De Reclactie van het blad vervolgt aldus:

De accountant, die een howolarium vi"aget, dat niet evenredig is aan het werk, dat hij feitelijk zou moeten verrichten om de opdracht goed te volrocren, maakt het zich bij voorbaat mocilijk zijn plicht jegens zijn eliënten goed na te komen. De man, die een deskundige raadplecgt verwacht, dat het verkiregen advies het beste advies zall zijn, dat de deskundige kan geven. 
Uitgaande van de veronderstelling, dat het advies nict mag worden beinvloed noch door onderbieding van het normale honorarium noch door een verksegen premie boven het honorarium, is het duidelijk, dat de algenneen gebluikclijke bepaling van het honorarium de juiste is.

Tooral bij de belastingzaken gaat dit op, daar hier het algemeen belang nooit geheel kan worden uitgesloten; de accountant heeft een publicke taak ten opzichte van den fiseus en cen private taak tegenover den client. Ilet zou cen jamp voor het beroep zijn, indien let vertrouwen van den fiscus in aecountants zou worden geschokt en hoe zou dit kumen worden voolkomen, indien de verdiensten van den accountant direct afhankelijk zou zijn van het bedrag, dat alan den fiscus wordt onthouden.

Aan den anderen kant kan men zich wel voorstellen, dat cliënten cen voorkeur hebben tot het aangaan vam een overeenkomst tot betaling op basis der bereikte resultaten. Indien een client van zijn kant een dergelijke regeling zou willen maken kan niemand dit verhinderen, docll zelfs in dat geval moet het beclrag, dat de accountant uiteindelijk verkijigt voor het grootste deel gebaseerd zijn op den aan de opdracht besteden tijel. Dat wil zecgenen, dat de client niet kan worden verhinderd on zijn voldoening in de behadde resultaten tot uiting te brengen cioor boven het normale honorarium een extra vergoeding to geven. Doch dit versehilt atamerkelijk van het declareeren door den accountant van ecn bedrag, dat in geen verhouding staat tot de werkelijk bewezen diensten als deskundige.

De Council heeft gemeend mede zijn oordeel over dit onderwerp te moeten uitspreken en deed dit op een vergadering van 7 Augustus 1935 aldus :

"That in the opinion of the Council it is highly undesirable that in Revenue cases members of the Institute should undertake work on the basis either that they should be remunerated by a pereentage on the amount recovered or that they should receive no remuncration if no recovery results. Should such a case be brought to the knowledge of the Couneil it will be liable to be regarded as discreditable conduct."

De algemeen geldende opinie werd dus door de Council bevestigd, een oordeel, waldrover wij ons nit het oogpunt van beroepsecr kumen verheugen.

\section{Een misleidend prospectus}

IIet is alweer een geruimen tijd geleden, dat de Royal Mail Case de gemoederen in beweging bracht. In het voorjaar 1935 heeft rich wederom een financieele debacle in Engeland voorgedaan, die hoewel niet van een dergelijke omvang als de genoemde zaak, veel stof heeft doen opwaaien. Wij hebben hier het oog op de debacle van de peper pool. Fen zekere overeenkomst tusschen beide gevallen is aanwezig, doordat een bij de peper pool betrokken instelling eveneens door middel van cen beroep op de geldmarkt den dans trachtte te ontspringen. Deze gelden konden verkregen worden door den juisten gang van zaken niet in het prospectus te vermelden.

De slechte afloop van de pool is genoegzaam bekend uit de berichten van de dagbladen; wij volstaan or dus mede het volgende to ontleenen aan een artikel voorkomende in het nummer vall 27 Juli van 'The Accountant.

Bezien van het standpunt van het beleggend publiek is het prospectus der firma James \& Shakspeare de kerm vall de grehecle zaak. Deze firma had de controle verkregen over Williams Henry \& Co, welke laatste groote verplichtingen had loopen door alankoopen van schellak en peper. Deze verpliehtingen gingen boven de krachten der firma en de Receiver vond niet alleen, dat het moeilijk was zich alan den indruk te onttrekken, dat de emissie werd opgezet met het eenige doel om de overgenomen onderneming te hulp te komen, doch ook, dat de betrachte spoed bij de enissie als ecn factor van het grootste gewicht werd beschouwd. Maar dat was niet alles. Het prospectus makkte geen molding van de kritieke situatie van Williams llenry \& Co. Kort gezegd, James \& Shakspeare had de contrổ. verworven over ecn firma, wier ongezonde speculaties deze op lien rand van den aferrond hadden gevoerd en het publick wer.d daama nitgenoodigd ,to hold the baby".

De inselirijvers werden opzettelijk in onkunde gelaten over re financiecle positie en de vooluitzichten der firma. ()prettelijk werden belangrijke feiten verzwegen, die, inclien deze openbar gemaakt zouden zijn geworden, tot het mislukken van de emissie geleid zouden hebben. I)och niet alleen werden feiten verzwegen, doch, it would appear to anyone reading the prospectus and the auditors' certificate, that Williams Menry \& $C_{0}$ Itd was in a sound financial condition."

Optimisme in cen prospectus is niet straflaal, doch het feit, clat het mogelijk is op cen nitnoodiging tot het geven van geld belangrijke gegevens te verzwijgen, die, indien deze bekcnd wa ren geweest, zelfs de meest oncrvaren belegger zou hebhen weerhouden in te schrijven, geeft cen gevocl van on'ust.

De Companies Act 1929 verlangt, dat cen prospectus cen accountants-verklaring zal bevatten, ,with respect to the profits of the company in respect of each of the three financial years immediately preceding the issue of the prospectus and the rates of the dividends (if any) paid by the company in respeet of each class of shares in the company in respect of the said three years". Thet is duidelijk, dat dit voorschrift den belegrger niet beschermt, indien de publicecring van winsten en dividenden gepaard gaat met cen verzwijging van het feit, dat de vennootschap buitensporige verplichtingen heeft loopen en aan den rand van het bankroet staat.

De accountants, die hun verklaping hebben afgegeven hebben verklaard, dat hun geen pepercontracten waren getoond; zelfs wisten zij niet, dat de vennootschap op eenigerlei wijze in peper was geinteresscerd.

De les, die de Redactie van The Accountant uit dit voorval trekt is, dat de bestaande wetgeving onvoldoende is. De Stock Exchange Committee zou wardevol werk verrichten door cen politiek te voeren, waarbij zij niet tot toelating tot de noteering der fondsen zal overgaan, tenzịj zịj ingelicht zou zijn betreffende de uitstaande verplichtingen.

ICet komt ons echter op zijn minst genomen vreemd voor, voor zoover wij op bovenstaande gegevens moeten afgaan, dat de accountant in liwestie zich onvoldoende rekenschap heeft gegeven van het doel, waarvoor de gevraagde gelden zouden mocten dienen en dat zij meenen te kumnen volstalan met de verklaring, dat zij niet wisten, dat de vennootschap in peper was geinteresseerd. Naar onze meening is de accountant volgens de hier te lande geldende opvattingen in zijn publicke taak tekort geschoten. Deze zaak werpt tevens het licht op le gevaren, die men loopt, indien de verantwoordelijkheid zich uitsluitend richt naar de bestaande jurisprudentic.

\section{Engelsch oordeel over het verslag der Royal Dutch}

In The Aceountant van $29 \mathrm{Juni} 1935$ komt in de rubriek Finance and Commerce het volgende oordeel voor betreffende het verslag der lioyal Duteh. "In the casc both the balance sheet and the profit and loss account are followed by ,explanations". 'I'hese add so much to the elarity of the figures that we reproduce them as illustrating what can be done when real effort is made to give shareholders the fullest understanding of the position".

CH. H. 